UDC 330.15

DOI: 10.46666/2021-2.2708-9991.07

https://www.jpra-kazniiapk.kz

\title{
GLOBAL EXPERIENCE OF TRANSITION TO A "GREEN" ECONOMY
}

\section{"ЖАСЫЛ" ЭКОНОМИКАҒА КӨШУДІҢ ӘЛЕМДІК ТӘЖІРИБЕСІ}

\section{МИРОВОЙ ОПЫТ ПЕРЕХОДА К «ЗЕЛЕНОЙ» ЭКОНОМИКЕ}

\author{
B.M. ISKAKOV* \\ C.E.Sc., Associate Professor \\ A.A. PYAGAY \\ D.E.SC., Professor \\ A.T. RAKHIMBEKOVA \\ Ph.D student \\ "Turan-Astana» University, Nur-Sultan, Kazakhstan \\ *corresponding author e-mail:iskakov82@mail.ru \\ Б.М. ИСКАКОВ \\ э.ғ.к., қауымдастырылған профрессор \\ А.А. ПЯГАЙ \\ э.Ғ.Ә., профрессор \\ A.T. РАХИМБЕКОВА \\ Ph.D докторанты \\ «Тұран-Астана» университеті, Нұр-Сұлтан, Қазақстан \\ *автордың электрондық поштасы: iskakov82@mail.ru \\ Б.М. ИСКАКОВ \\ к.э.н., ассоциированный профрессор \\ А.А. ПЯГАЙ \\ Ә.э.н., профрессор \\ A.T. РАХИМБЕКОВА \\ докторант Ph.D \\ Университет «Туран-Астана», Нур-Султан, Казахстан \\ *электронная почта автора: iskakov82@mail.ru
}

\begin{abstract}
The goal is to consider the priority areas of green economy concept: principles, factors, mechanisms and prerequisites for Kazakhstan's transition to the implementation of environmental policy. Objectives - to show the need to develop government programs for the long term and their stages to move towards ecosystems; substantiate that the dynamics of response and effective functioning of the labor market play a key role in facilitating transformation to a resource-saving economy, increasing the number of jobs in this industry. "Green" growth is also an opportunity to expand the labor market. At present, the totality of global environmental and economic threats and challenges has put the world economic science in front of the need to search for new ways of developing the world economy. Methods - in the research methods of scientific analysis, comparison and synthesis were used. Results - the authors carried out a search and proposed a formulation of the most accurate and capacious modern definition of eco-innovation, which unambiguously reflects their essence. Domestic and international scientific developments on the issue of sustainable development of a new model for reducing environmental deficit have been studied. Conclusions - the authors state that in order to comply with international standards, agricultural sector of the republic needs to be updated. Expansion of the organic agriculture sector could be an alternative to the existing management models. The article also focuses on the fact that the concept of "green" economy does not replace the strategy of stable forward movement, but focuses on "green" sectors as new engines of growth aimed at improving the quality of life of the population while minimizing the depletion of natural resources and preserving nature.
\end{abstract}

Аңдатпа. Мақсаты - "жасыл" экономика тұжырымдамасының басым бағыттарын: Қазақстанның экологиялық саясатты іске асыруға көшуі үшін қағидаттарды, фракторларды, тетіктер мен алғышарттарды қарастыру. Міндетmері - ұзақ мерзімді перспективаға 
$\bullet \bullet \bullet \bullet \bullet \bullet \bullet \bullet \bullet \bullet \bullet \bullet \bullet \bullet \bullet \bullet \bullet \bullet \bullet \bullet \bullet \bullet \bullet \bullet \bullet \bullet \bullet \bullet \bullet \bullet \bullet \bullet \bullet \bullet \bullet \bullet \bullet \bullet \bullet \bullet \bullet \bullet \bullet \bullet \bullet \bullet \bullet \bullet \bullet \bullet \bullet \bullet$ арналған мемлекеттік бағдарламаларды және олардың экожүйелерге қарай жылжуы үшін кезеңдерін әзірлеу қажеттілігін көрсету; ден қою серпіні мен еңбек нарығының тиімді жұмыс істеуі ресурс үнемдейтін экономикаға трансформациялауға жәрдемдесуде, осы саладағы жұмыс орындарының санын арттыруда түйінді рөл атқаратынын негіздеу. "Жасыл" өсу бір мезгілде еңбек ресурстары нарығын кеңейту мүмкіндігі болып табылады. Қазіргі уақытта жаһандық экологиялық және экономикалық қауіптер мен сын-тегеуріндердің жиынтығы әлемдік экономикалық ғылымды әлемдік экономиканы дамытудың жаңа жолдарын іздеу қажеттілігіне алып келді. Әдістер - зерттеу барысында ғылыми талдау, салыстыру және синтез әдістері қолданылған. Нәтижелері - авторлар эко-инновациялардың ең дәл және ауқымды заманауи анықтамасын іздеуді жүзеге асырған және ұсынған, бұл олардың мәнін нақты көрсетеді. Экологиялық тапшылықты төмендетудің жаңа моделін тұрақты дамыту тақырыбы бойынша отандық және халықаралық ғылыми әзірлемелер зерделенген. Қорытындылар - авторлар әлемдік стандарттарға сай болу үшін республиканың аграрлық секторы жаңартуды талап етеді деп тұжырымдайды. Пайдаланылатын басқару модельдеріне балама органикалық ауылшаруашылық секторын кеңейту болуы мүмкін. Мақалада сондай-ақ "жасыл" экономика тұжырымдамасы тұрақты ілгерілемелі қозғалыс стратегиясын алмастырмайтындығына, бірақ табиғи ресурстардың сарқылуы мен табиғатты сақтауды барынша азайта отырып, халықтың өмір сүру сапасын арттыруға бағытталған өсудің жаңа қозғалтқыштары ретінде "жасыл" секторларға баса назар аударылатынына назар аударылады.

Аннотация. Цель - рассмотрение приоритетных направлений концепции «зеленой» экономики: принципов, факторов, механизмов и предпосылок для перехода Казахстана к реализации экологической политики. Задачи - показать необходимость разработки государственных программ на долгосрочную перспективу и их этапов для продвижения к экосистемам; обосновать, что динамика реагирования и эффрективное функционирование рынка труда играют ключевую роль в содействии трансформации к ресурсосберегающей экономике, увеличению числа рабочих мест в данной отрасли. «Зеленый» рост является одновременно возможностью для расширения рынка трудовых ресурсов. В настоящее время совокупность глобальных экологических и экономических угроз и вызовов поставила мировую экономическую науку перед необходимостью поиска новых путей развития мировой экономики. Методы - в процессе исследования использовались методы научного анализа, сравнения и синтеза. Результаты - авторы осуществили поиск и предложили формулировку наиболее точного и емкого современного определения эко-инноваций, которое однозначно отражает их сущность. Изучены отечественные и международные научные разработки по теме устойчивого развития новой модели снижения экологического дефицита. Выводы - авторы констатируют, что для соответствия мировым стандартам аграрный сектор республики требует обновления. Альтернативой используемым моделям управления может стать расширение сектора органического сельского хозяйства. В статье также акцентируется внимание на том, что концепция «зеленой» экономики не заменяет стратегию стабильного поступательного движения, но делает упор на «зеленые» секторы как на новые двигатели роста, направленные на повышение качества жизни населения при минимизации истощения природных ресурсов и сохранения природы.

Key words: agriculture, "green" economy, foreign experience, global environmental and economic threats and challenges, environmental deficit, quality of life of the population.

Түйінді сөздер: ауыл шаруашылығы, "Жасыл" экономика, шетелдік тәжірибе, жаһандық экологиялық және экономикалық қауіптер мен сын-қатерлер, экологиялық тапшылық, халықтың өмір сүру сапасы.

Ключевые слова: сельское хозяйство, «зеленая» экономика, зарубежный опыт, глобальные экологические и экономические угрозы и вызовы, экологический дефицит, качество жизни населения.

Introduction. The inevitable feature of the "green» economy is globalization, when all countries of the world unite their efforts to improve the environment. This important law has revealed national identity or differences, and has also been adopted to improve national legislation governing carbon emissions.
The need, she noted, is the possibility of a transition to a "green» economy, which should be carried out taking into account individual national interests [1]. Financial institutions are representatives of business, business, government of individual countries, entrepreneurs and consumers. 
The «green» economy is an economic trend that has developed over the past two decades, and it is believed that the economy is related to the natural component of the environment that is part of its existence. The three main axioms of economic theory are based on three axioms: limited opportunities spread over a long time, the sphere of influence expands; in the face of growing demand with limited resources; to be connected to every thing on earth.

Continuous economic growth is not possible only continuous economic growth is possible. The concept of a "green» economy is increasingly attracting public attention. It is actively discussed by experts, politicians and public organizations. Proponents of the «green» economy concept believe that the current economic system is currently imperfect.

The concept of a "green» economy that has emerged over the past two decades is designed to ensure a more harmonious alignment between these three components social, natural, and economic-that would be acceptable to all groups of countries - developed, developing, and transition economies. The concept of "green» economy includes the ideas of many other areas in economic science and philosophy (feminist economics, postmodernism, environmental economics, environmental economics, anti-globalism, theory of international relations, etc.) related to the problems of sustainable development.

Material and methods of research. Although it has led to some results in improving the standard of living of people in general and, in particular, of a group of individuals (or groups of countries), the negative consequences of the functioning of such a system are the most important of them: environmental problems, climate change, desertification, loss of biodiversity), depletion of natural capital, widespread poverty, lack of water, food and energy, the needs of people and places. All this poses a threat to present and future generations [2].

In order to reorient the global economy towards a stable model of economic, social and environmental growth, the principles of the «green» economy must be integrated into the structural reforms currently under way. Experts identify four main channels (identifying their respective effects) through which the formation of a «green» economy and related structural reforms could serve as engines of economic growth, which also includes an increase in GDP.

First, the transition to a «green» economy can increase access to natural, physical and human capital resources (these are input effects). We are talking about increasing the productivity of natural resources (forests, fish, farmland, etc.) by better managing natural capital, improving the quality of human potential by improving health and reducing morbidity by improving the state of the environment, and, finally, reducing the economic damage from the loss of human potential [3].

At the same time, the proposed modern concept of a «green» economy directly indicates the vector of growth, the greening of the modern economy and the direction of growth, this is the creation of new environmentally friendly industries due to demand from the state and the formation of a new demand and a new culture of consumption from society.

In the course of the research, a systematic approach, an evolutionary approach, and approaches of the theory of sustainable development were used. The methods of analysis and synthesis, grouping and comparison are used as the methodological apparatus of the study.

Results and their discussion. Secondly, this transition should be accompanied by favorable structural changes and include significant investments in a number of system-forming industries, including energy, construction, housing and utilities, etc., aimed at modernizing the production apparatus, improving energy efficiency, switching to alternative energy sources and reducing greenhouse gas emissions.

All these results are reflected in improving the efficiency of the basic sectors of the economy (the efficiency effect). At the same time, third, investments in green infrastructure development, including water and sewerage systems, public transport focused on alternative fuel resources, and others, are independent, identified as an important growth factor.

Special attention in the transition to a "green» economy is paid to the formation of modern infrastructure, which is a key factor.

Infrastructure sectors include water infrastructure, including dams and reservoirs), land management and land management, housing and urban development, coastal protection, flood systems and road infrastructure, including ports, bridges, roads), energy (including nuclear power plants), and others.

These industries are characterized by a long service life of the equipment used in them (for ranking a number of industries from 20 to 200 years) and a long-term investment character, as a result of which their use in the context of modernization is crucial. At the same time, infrastructure sectors are characterized by emphasized economies of scale, network effects, and synergies between economic, environmental, and social objectives, 
which increase the efficiency of the respective investments [4].

Even in some countries, this method of forming a modern economy, considering it a priority in this area. In South Korea concept of the "green» economy is focused on the good quality of the national industry, investment and energy, transportation, alternative sources of fresh water, waste recycling technology, regulation and development of small towns. Politicians also argue that when implementing various projects, regardless of their implementation, a single package is created to avoid budget costs for another plan [5].

Since 2011 the company has been implementing a green card incentive system for the use of environmental innovations in the production of green home goods in South Korea. This account card uses «green» goods and services used instead of private public transport, as well as home consumer goods. This experience in Kazakhstan, in our opinion, seems very interesting, especially when it comes to the national payment system. Maybe this includes a «green» component.

The United States of America, which has chosen ecology as one of the main directions for the development of alternative energy. The production of solar equipment accounts for $65 \%$ of the country's energy and $35 \%$ of annual revenue by 2030 relative to the US authorities. b.a. - this is when two years (2014) were independent, then concrete measures were taken to achieve this goal [6].

Almost all EU countries have large-scale programs in the field of «green» energy, the development of public transport and infrastructure, the construction of eco-settlements, as well as waste protection systems. The recent approval of the Strategy for the development of the national economy began with the fact that the UK presented its projects-clean «green» technologies, the creation of new jobs, over 100000 people.

Kazakhstan has unique opportunities and prerequisites for economic development. The huge economy, the favorable geopolitical position, the availability of financial and natural resources, the increased supply of green technologies on the open market, and other factors create new opportunities for efficient and comfortable use. The most important segment from the point of view of «green» economic development, which includes the needs, the waste management sector, is the energy sector and the water consumption sector.

After the summits, the green society of Kazakhstan will be engaged in the implemen- tation of the transition to the Russia +20 strategy. At the initiative of President Nursultan Nazarbayev, We will proceed to the development of the concept of a "green" economy. First, this issue is a priority development concept that is primarily focused on reforming individual sectors of the economy.

The lack of competition between the «green» and "clean» level of global economic development leads to a gap between Kazakhstan in terms of improving competitiveness and technology. The key segment where economic growth can develop is shown in table.

We will try to help the "green» economy in this regard.In general, we can give the following figures:

- in the forest sector, we have a great variety. The absolute majority of the population of this planet is not concentrated in the forest sector, but in the development of the forest ecosystem, such as in the field of nature protection and health, ecosystem ecology. The regional budget provides for a systematic approach to solving social problems, as well as increasing the transparency and openness of the budget process and budget data for the whole country;

- «green» agriculture Gradually the intensity of agriculture is how many plants should migrate, reducing the load, fighting diseases and common aerosol problems. There should be changes in the policy, first of all, its reduction and, ultimately, the termination of the provision of environmentally harmful subsidies, causing confusion in the reality of the cost of agricultural products;

- water Resources Management Is Stable. The wells are able to meet the demand for fresh water. Institutional reform mechanisms were improved, land use schemes were changed, as well as improved support and allocation of funds; investment subsidies were reduced; water payment and financing schemes were changed. At the same time, it is necessary to radically increase investments in the rural sewerage and water supply system;

- renewing energy sources. It is expected that the use of technology, the modernization of energy sources, the improvement of living standards and the improvement of energy policies related to the health of the population due to economic conditions and low income of the population, especially after their connection to the communication networks. Cost-effective solutions for the commissioning of new equipment that will preserve the planet's autonomous biomass without compromising costs; 
Table - Economic development in the economy segment

\begin{tabular}{|c|c|}
\hline Segment & Directions \\
\hline Generation of energy & $\begin{array}{l}\text { wind power generation solar } \\
\text { hydra / marine } \\
\text { biofuel geothermal }\end{array}$ \\
\hline Energy storage & $\begin{array}{l}\text { fuel cell } \\
\text { Improved batteries } \\
\text { hybrid systems }\end{array}$ \\
\hline Energy infrastructure & $\begin{array}{l}\text { management } \\
\text { broadcast }\end{array}$ \\
\hline Energy efficiency & $\begin{array}{l}\text { lighting } \\
\text { buildings } \\
\text { glass }\end{array}$ \\
\hline Transportation & $\begin{array}{l}\text { vehicles } \\
\text { logistics } \\
\text { structure fuel }\end{array}$ \\
\hline Water and waste water & $\begin{array}{l}\text { water purification } \\
\text { water protection } \\
\text { cleaning of drains }\end{array}$ \\
\hline Air and environment & $\begin{array}{l}\text { cleaning / safety } \\
\text { emission control } \\
\text { monitoring / compliance } \\
\text { trade and compensation }\end{array}$ \\
\hline Materials & $\begin{array}{l}\text { nano } \\
\text { bio } \\
\text { chemical }\end{array}$ \\
\hline Manufacturing/Industry & $\begin{array}{l}\text { advanced packaging } \\
\text { monitoring and control } \\
\text { smart manufacturing }\end{array}$ \\
\hline Agriculture & $\begin{array}{l}\text { natural pesticides } \\
\text { land management } \\
\text { aquaculture }\end{array}$ \\
\hline Recycling and waste & $\begin{array}{l}\text { recycling } \\
\text { waste management }\end{array}$ \\
\hline
\end{tabular}

- tourism development. The development of tourism contributes to the development of the local economy and the reduction of poverty. The tourist contributes to a more "green» industry, which ecotourism says is growing $20 \%$ faster six times more than tourism in general. Tourism includes industry and travel management, where the majority of human resources are required to employ 230 million people, or $8 \%$ of the global workforce. About half of them are related to the industrytourism, which creates additional jobs. Green Week is expected to have been boosted by capacity expansion to the wider sector and wider employment combined with local resources. It is an important factor in the development of the economy, there is a process of reducing the tourism sector, as well as more active involvement of local communities in the process of local greening, especially for the poorest segments of the population, the creation of tourist networks;

- use and Management of waste. In addition to the appeals of citizens related to the development of employment, there is a problem of waste disposal and waste disposal with the growth and development of income of the population the main thing in this sector is the lack of jobs. Processing and recycling is 10 times more than material handling, restarting, or incineration. In the "green investment» scenario of the industry's workforce development, the remaining turnover is projected to increase by $10 \%$ compared to current trends. Rustem Khamitov said, what we need additional potential in the field of employment with industrial waste, the possibility of their reuse and elimination, as well as improving jobs in this sector. There is also a "green» option for jobs to meet the requirements that must serve such criteria, including minimum wage, other than jobs, labor protection, and so on.

Development of a methodology for generating funds necessary for the regional stage: investment policy of government authorities, investment attraction analytics, regional tourist and recreational zone of the FEZ. The price should be calculated based on the developed 
system of balancing investments in the tourist and recreational region of attractiveness, which is based on the following principles:

- on a scientific basis, a set of factors and models that affect the recreational areas and investment attractiveness of the region is explained;

- tourist and recreational zone «specific goals for the development of the region in terms of investment attractiveness»;

- it is considered as a single stable region of tourist complex objects, as well as complementary elements;

- we have a wide variety of tourist and entertainment areas, where each of them describes certain indicators that determine the investment attractiveness of the region;

- design of socio-economic and investment processes for the adequate development of tourist and recreational territory;

- efficiency-attracting investment in the recreational area and the ability to make reliable regional investment decisions;

- continuity-indicators that affect the cost assessment of the quality of adaptation to the receipt of new information;

- reliability, accuracy, and validity;

- tourist and recreational zone «specific goals for the development of the region in terms of investment attractiveness»;

- it is considered as a single stable region of tourist complex objects, as well as complementary elements;

- we have a wide variety of tourist and entertainment areas.where each of them describes certain indicators that determine the investment attractiveness of the region;

- regionalization of the tourist and recreational territory of the socio-economic and investment processes of adequate industrialization;

- efficiency-attracting investment in the recreational zone and the ability to make reliable regional investment decisions;

- continuity-indicators that affect the cost assessment of the quality of adaptation to new information;

- trust, validity, and accuracy.

It is connected with the development of the tourism industry, in addition, it gives meaning to the fact that the state supports it [7].

It is safe to say that the tourism industry today is one of the priority sectors of the economy of Kazakhstan. It was developed on the basis of the tourism development strategy, and the state program for its implementation was approved. The development concept provides for the creation of a positive image, the definition of the main directions of tourism, tourism activities and the creation of favorable conditions for the development of tourism.

An integral part of the economic development strategy of the Republic of Kazakhstan is the attraction of foreign investment in the tourism industry. First of all, along with attracting long-term investment capital, it provides new technologies, innovations and new jobs.

Foreign investment in recent years, economic development and tourism have contributed to increasing economic and political stability in Kazakhstan. The main task of the state should be to attract foreign investment now and maintain positive trends, as well as to improve the investment climate in the country.

The transition to the economy of Kazakhstan is expected: increasing the efficiency of resource use, improving the infrastructure of Kazakhstan; improving the security of the country's population [8].

Turning to the main problem, the "green» economy that countries face is as follows: improving the efficiency of resource management and use (water, land, biology, etc.); modernization and construction of existing infrastructure; improving the quality and safety of the environment, reducing pressure on the environment at the expense of the population, which is a cost-effective way; improving national security, including water safety.

Conclusion. The Republic of Kazakhstan has a three-stage development concept for implementing the transition to the economy.

The first period is from 2020 to 2013, which outlines the main priorities of the state's activities to improve the efficiency and optimization of the use of natural resources, as well as «green» infrastructure.

Use of resources covering the water path towards a green infrastructure framework for the second phase from 2020 to 2030-led to the beginning of the economic transformation of the national economy, stimulate the development and implementation of technologies and modernization for widely used sources of energy and the establishment of the highest standards of efficiency in the structure of the construction.

The third stage is the "third industrial revolution», named after the principle of motion of the national economy: from 2050 to 2030, denial and restoring natural resources for their recovery is stable [9].

The seven main areas include the «green» economy: sources;

- introduction of renewable energy

- this is the efficiency of housing and communal services; 
organic farming, agriculture;

- improvement of the mining management system;

- improving the water resources management system;

- transport development;

- effective management and protection of the ecosystem.

Within the framework of the main investment program for the development of the economy of Kazakhstan, the main sectors of the economy are 10: agriculture, housing and communal services, energy, fishing, forestry, industry, tourism, transport, waste processing and disposal, water resources management [10].

According to the assessment, the transformation into 2050 is an additional opportunity for the "green» economy in the context of: 3 percent of GDP, the creation of more than 500 thousand new jobs, a new form of employment and services, as well as ensuring the quality of life of the population anywhere in the world.

World experience shows that the "green» economy is aimed at stimulating regional development, increasing social stability and economic potential, creating new jobs and the «green» economy.

Kazakhstan is interested in the economy and popularity. Therefore, important factors that contribute to economic development and GDP growth, increase domestic income and create jobs for the population, and reduce the unemployment rate in the country.

At the same time, climate change, such as the weakening of global threats or the transition to a global economy, is being weakened by the lack of minerals.

\section{Rereferences}

[1] Смагулова, Ж.Б. Анализ мирового опыта перехода к зеленой экономике: предпосылки и направления / Ж.Б. Смагулова, А.Е. Муханова, Г.И. Мусаева // Международный журнал прикладных и фундаментальных исследований. - 2019. - № 3. - С. 92-96.

[2] Исаак, А. Зеленая экономика - шанс для устойчивого развития Молдовы.- 2014.URL:https://nskee.energohelp.com/articles/org/7 930/ (дата обращения: 15.04.2021).

[3] Priorities of the Concept of transition of the Republic of Kazakhstan to sustainable development. - Almaty: De Luxe, 2019. - P. 42-45.

[4] Балтабаева, А.М. Қазақстан Республикасының аграрлық секторының аймақтық дамуы / А.М. Балтабаева // Проблемы агрорынка. -2017.-№3. -Б. 125-130.

[5] Егорова, М.С. Содержание «зелёной» экономики: цели и задачи / М.С.Егорова //
Современная экономика: проблемы и решения. - 2014. - №12(60). - С. 154-166.

[6] Григорук, В.В., Климов, Е.В. Развитие органического сельского хозяйства в мире и Казахстане [Электронный ресурс].- 2016.URL: https://www.fao.org/3/a-i5454r.pdf (дата обращения: 19.04.2021).

[7] Атенова, А.М. Социально-экономические перспективы развития туризма в Казахстане [Электронный ресурс] / А.М. Атенова, А.Е. Есенова, Г.М. Арапова, Ж.М. Кетпен [Электронный ресурc].-2017. - URL: https:// group-global.org/ru/node/219999 (дата обращения: 25.08.2017).

[8] Пискулова, Н. Глобальные проблемы. Экологическая политика как фактор международной конкурентоспособности государств / Н. Пискулова // Мировая экономика и международные отношения.-2014.-№7.-С.48-53.

[9] Дабылтаева, Н.Е. Инвестиционноинновационная стратегия развития агропромышленного комплекса Казахстана в международном разделении труда / Н.Е. Дабылтаева // Вестник КазНУ.- 2014.- N (68). C.81-87

[10] Байжолова, Р.А. Проблемы и перспективы формирования «зеленой экономики» в Казахстане/ Р.А.Байжолова, Ж.М. Орынканова// Вестник университета «Туран». - 2019. - № 1 (81). - С. 182-186.

\section{Rereferences}

[1] Smagulova, Zh.B., Mukhanova, A.E. \& Musayeva G.I. (2019). Analiz mirovogo opyta perekhoda k zelenoi ekonomike: predposylki i napravleniya [Analysis of the world experience of the transition to a green economy: background and direction]. Mezhdunarodnyi zhurnal prikladnyh i fundamental'nyh issledovanij - International Journal of Applied and Fundamental Researches, 3, $92-96$ [in Russian].

[2] Isaak, A. (2014). Zelenaya ekonomika shans dlya ustoichivogo razvitiya Moldovy [Green Economy - a Chance for Sustainable Development of Moldova]. - 2014 - Available at: https://www. nskee.energohelp.com/ articles/ org/ 7930/.html (date of access: 15.04.2021) [in Russian].

[3] Priorities of the Concept of transition of the Republic of Kazakhstan to sustainable development (2019). Almaty: De Luxe, 42-45.

[4] Baltabaeva, A.M. (2017). Qazaqstan Respublikasynyñ agrarlyq sektorynyñ aimaqtyq damuy [Regional development of the agricultural sector of the Republic of Kazakhstan]. Problemy agrorynka - Problems of AgriMarket, 3,125-130 [in Kazakh].

[5] Egorova, M.S. (2014). Soderzhanie «zelyonoj» ekonomiki: celi i zadachi [Contents of "green" economies: goals and objectives]. Sovremennaya ekonomika: problemy i resheni- 
ya - Modern economy: problems and solutions, 12 (60), 154-166 [in Russian].

[6] Grigoruk, V.V. \& Klimov, E.V. Razvitie organicheskogo sel'skogo hozyaistva $v$ mire i Kazakhstane [Development of organic agriculture in the world and in Kazakhstan]. - 2016. Available at: https://www.fao.org/3/a-i5454r.pdf (date of access: 19.04.2021) [in Russian].

[7] Atenova, A.M., Yessenova A.E., Arapova G.M. \& Ketpen Zh.M. Social'no-ekonomicheskie perspektivy razvitiya turizma $\mathrm{v}$ Kazahstane [Socio-economic prospects of tourism development in Kazakhstan]. - 2017. - Available at: https://group-global.org/ru/node/219999 (date of access: 25.08.2017) [in Russian].

[8] Piskulova, N. (2014). Global'nye problemy. Ekologicheskaya politika kak faktor mezhdunarodnoj konkurentosposobnosti gosudarstv [Global problems. Environmental policy as a factor in the international competitiveness of states]. Mirovaya ekonomika $i$ mezhdunarodnye otnosheniya - World Economy and International Relations, 7, 48-53 [in Russian].

[9] Dabyltaeva, N.E. (2014). Investicionnoinnovacionnaya strategiya razvitiya agropromyshlennogo kompleksa Kazahstana v mezhdunarodnom razdelenii truda [Investment and innovation strategy for the development of the agro-industrial complex of Kazakhstan in the international division of labor]. Vestnik KazNU Bulletin of KazNU, 68, 81-87 [in Russian].

[10] Baizholova, R.A. \& Orynkanova Zh.M. (2019). Problemy i perspektivy formirovaniya «zelenoi ekonomiki» v Kazakhstane [Problems and prospects of the formation of a "green economy" in Kazakhstan]. Vestnik universiteta "Turan» - Bulletin of the University "Turan", 1(81), 182-186 [in Russian].

\section{Information about the authors:}

Iskakov Bauyrzhan Muratbekuly -The main author; Candidate of Economic Sciences, Associate Professor; Professor of the Department of Economics and Innovative Business; "Turan-Astana» University; 010000 Y.Dukenuly str., 29, Nur-Sultan, Kazakhstan; e-mail:iskakov82@mail.ru; https://orcid.org/0000-0002-3989-7631

Pyagai Alexander Anatolyevich; Doctor of Economic Sciences, Professor; Professor of the Department «Economics and Innovative Business»; «Turan-Astana» University; 010000 Y.Dukenuly str., 29, Nur-Sultan, Kazakhstan; e-mail: pyagay72@mail.ru; https://orcid.org/0000-0002-1590-872X

Rakhimbekova Aliya Toleutaevna; Ph.D student of Department of «Economics and Innovative Business»; "Turan-Astana» University, 010000 Y.Dukenuly str., 29, Nur-Sultan, Kazakhstan; e-mail: arat2901@gmail.com; https://orcid.org/0000-0003-0497-7508

\section{Авторлар туралы ақпарат:}

Искаков Бауыржан Мұратбекұлы - негізгі автор; экономика ғылымдарының кандидаты, қауымдастырылған профессор; «Экономика және инновациялық бизнес» кафедрасының профрессоры; «Тұран-Астана» университеті; 010000 Ы.Дүкенұлы көш., 29, Нұр-Сұлтан қ., Қазақстан; e-mail: iskakov82@mail.ru; https://orcid.org/0000-0002-3989-7631

Пягай Александр Анатольевич; экономика ғылымдарының докторы, профессор; «Экономика және инновациялық бизнес» кафедрасының профессоры; «Тұран-Астана» университеті; 010000 Ы.Дүкенұлы көш., 29, Нұр-Сұлтан қ., Қазақстан; e-mail: pyagay72@mail.ru; https://orcid.org/00000002-1590-872X

Рахимбекова Алия Төлеутайқызы; Ph.D докторанты «Экономика және инновациялық бизнес» кафедрасының; «Тұран-Астана» университеті; 010000 Ы.Дүкенұлы көш., 29, Нұр-Сұлтан қ., Қазақстан; e-mail: arat2901@gmail.com; https://orcid.org/0000-0003-0497-7508

\section{Информация об авторах:}

Искаков Бауыржан Мұратбекұлы - основной автор; кандидат экономических наук, ассоциированный профессор; профессор кафедры «Экономика и инновационный бизнес»; Университет «Туран-Астана»; 010000 ул. Ы.Дукенулы, 29, г.Нур-Султан, Казахстан; e-mail: iskakov82@mail.ru; https://orcid.org/0000-0002-3989-7631

Пягай Александр Анатольевич; доктор экономических наук, профессор; профессор кафедры «Экономика и инновационный бизнес»; Университет «Туран-Астана»; 010000 ул. Ы.Дукенулы, 29, г.Нур-Султан, Казахстан; e-mail: pyagay72@mail.ru; https://orcid.org/0000-0002-1590-872X

Рахимбекова Алия Толеутаевна; докторант Ph.D кафедры «Экономика и инновационный бизнес»; Университет «Туран-Астана»; 010000 ул. Ы.Дукенулы, 29, г.Нур-Султан, Казахстан; e-mail: arat2901@gmail.com; https://orcid.org/0000-0003-0497-7508 